\title{
Nitrogen and potassium in cover fertilization of cotton in latossols with different clay content
}

Liliane Oliveira Lopes ${ }^{1 *}$, Julian Junio de Jesus Lacerda', Rafael Felippe Ratke', Sammy Sidney Rocha Matias², Márcio Cleto Soares de Moura ${ }^{3}$, Raphael Lira Araujo 3

\author{
Federal University of Piauí, Bom Jesus, PI, Brazil \\ ${ }_{2}$ Piaui State University, Corrente, PI, Brazil \\ 3 Federal University of Piauí, Teresina, PI, Brazil \\ *Corresponding author, e-mail: liliane_ol@hotmail.com
}

\begin{abstract}
Nitrogen and potassium are the most extracted nutrients by cotton, making necessary the replacement by fertilization. Thus, the present study aimed to evaluate the cotton yield under different nitrogen and potassium doses as cover fertilization in latosols with different textures, in a 'Cerrado' biome area. The experiment was carried out at the Harmonia Farm, municipality of Sapezal - MT, Brazil. The experiment was carried out in a randomized blocks design, with four repetitions. Treatments were arranged in an incomplete fractional triple factorial scheme $(3 / 4) 4^{2} \times 2$, totaling 72 experimental units. The $N$ doses consisted of $46,69,92$ and $115 \mathrm{~kg} \mathrm{ha}^{-1}$ and the four $\mathrm{K}_{2} \mathrm{O}$ doses of $62,93,124$ and $155 \mathrm{~kg} \mathrm{ha}^{-1}$, with different combinations for the cover fertilization of the cotton crop, in two areas, one with 420 and other with $625 \mathrm{~g} \mathrm{~kg}^{-1}$ of clay. Cotton yield depends on the soil clay content. Appropriate doses of $\mathrm{N}$ and $\mathrm{K}$, applied together on cover can increase the cotton yield in $1508 \mathrm{~kg} \mathrm{ha}^{-1}$, when compared to control. Under the experimental conditions, it is suggested the application of $78 \mathrm{~kg} \mathrm{ha}^{-1}$ of $\mathrm{N}$ and $155 \mathrm{~kg} \mathrm{ha}^{-1}$ of $\mathrm{K}_{2} \mathrm{O}$ as cover fertilization for a soil with $420 \mathrm{~g} \mathrm{~kg}^{-1}$ of clay and $71 \mathrm{~kg} \mathrm{ha}^{-1}$ of $\mathrm{N}$ and $124 \mathrm{~kg} \mathrm{ha}^{-1}$ of $\mathrm{K}_{2} \mathrm{O}$ as cover fertilization on soils with the clay content of $625 \mathrm{~g} \mathrm{~kg}^{-1}$.
\end{abstract}

Keywords: fertilization, Gossypium hirsutum L, Soil texture

\section{Introduction}

The cotton crop occupies about $2.5 \%$ of the world's arable land area and is responsible for the production of $33-36 \%$ of the consumed fiber (FAO \& ICAC, 2013). It is a crop that adapts to hothumid to sub-humid environments, in the tropics and subtropics, in different cropping systems, in soils with varied clay contents (Franzluebbers et al, 2012; Fultz et al., 2013; Kintche rt al., 2010).

In Brazil, approximately $94 \%$ of the area planted with cotton is located in the cerrado biome (CONAB, 2014). The Cerrado region is privileged, because it has adequate climatic conditions for cotton cultivation, as well as soils with flat topography, which facilitates mechanization. However, it presents chemical limitations due to its low natural fertility, being necessary the soil fertilization to achieve the full productive potencial of the crop (Souza et al., 2011).

In relation to macronutrients, the cotton crop is more demanding in potassium (K) and nitrogen $(N)$, followed by calcium, magnesium, phosphorus and sulfur (Borin et al., 2015). Potassium is necessary for the growth and development of cotton plants, and has a substantial impact on increasing yield (Harper et al., 2012; Dong et al., 2010). The absorption of $K$ by the cotton plant depends on several factors, among them, the genetic material, the $\mathrm{K}$ content in the soil, the 
fertilizer and the cultivation history of the area (Zhao et al., 2014; Pettigrew, 2008).

Nitrogen is the most widely used nutrient for cotton production (Yang et al., 2012, Bondada \& Oosterhuis, 2013). In some cotton fields in Australia, Rochester (2011) reports the possibility of reducing $15-25 \%$ (equivalent to $50 \mathrm{~kg} \mathrm{ha}^{-1}$ of N) of the total amount applied, without loss of production. Thus, before the recommendation of nitrogen fertilizers, it is necessary to take into account, among other factors, the residual $\mathrm{N}$ of previous crops, aiming to increase the application efficiency (Devkota et al., 2013).

The availability of $N$ and $K$ in the soil is related to $C E C$, soil buffer power and nutrient transport to the roots, these factors depend directly on the soil contents of clay and organic matter (Ernani et al., 2007). In this context, associate the application of adequate $\mathrm{N}$ and $\mathrm{K}$ doses in the period of greater demand by the cotton crop and considering the soil clay content can be a key approach to increase the crop yield.

Thus, the objective of the present study was to evaluate the crop yield under nitrogen and potassium doses in cover fertilization, in soils of different textures in the Cerrado biome area.

\section{Material and Methods}

The study was carried out in commercial cotton farm, managed in the conventional system, at the Harmonia Farm, ABC Agrícola Group, distant approximately $38 \mathrm{~km}$ from the municipality of Sapezal-MT, Brazil. The geographical coordinates of the experimental area are $84^{\circ} 71^{\prime} 39.2^{\prime \prime}$ north latitude, $30^{\circ} 97^{\prime}$ 53.7" east longitude and $581 \mathrm{~m}$ of altitude. The monthly rainfall during the conduction of the experiment, from January to September 2014, is described in Figure 1.

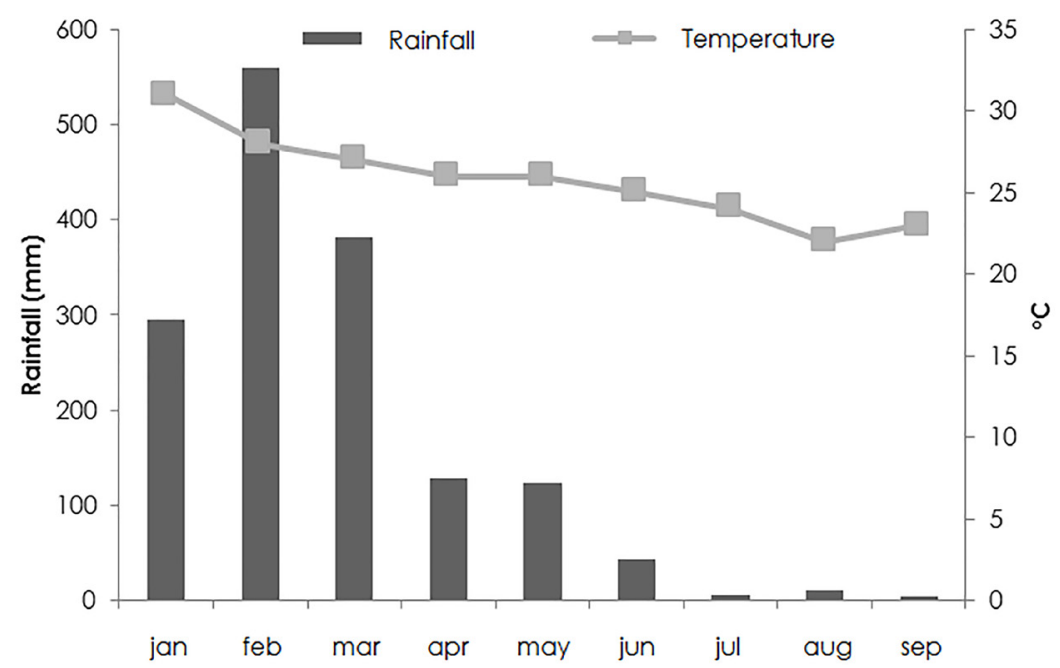

Figure 1. Rainfall and temperature during the experiment. (Source: Harmonia Farm, Sapezal, MT, Brazil, 2014.)

The physical and chemical characterization of the soil in the two evaluated areas before the experiment conduction is described in Table 1. The soil of the two areas was classified as a red dystrophic latosol (Santos et al., 2013). The area 1 with 420, 460 and 120 $\mathrm{g} \mathrm{kg}^{-1}$ of clay, sand and silt, respectively, of clayey texture, presented the previous history of fallow for six months, followed by soybean cultivation. Area 2 with 625, 210 and $165 \mathrm{~g} \mathrm{~kg}^{-1}$ of clay, sand and silt, respectively, with a very clayey texture, presented the previous history of succession growth of corn and soybean. The soybean cultivated in the two areas in the year prior to the experiment (2013) was the TMG 123 variety, with a population of 350,000 plants $\mathrm{ha}^{-1}$. The fertilization used in this crop was based on the specialized advisor of the MT Foundation. A total of $62 \mathrm{~kg} \mathrm{ha}^{-1}$ of $\mathrm{K}_{2} \mathrm{O}$ (source $\mathrm{KCl}$, with $62 \%$ of $\mathrm{K} 2 \mathrm{O}$ ) and $25 \mathrm{~kg} \mathrm{ha}^{-1}$ of sulfur (sulfugran, with $90 \%$ of S) were applied 30 days before planting, with 286 $\mathrm{kg} \mathrm{ha}^{-1}$ of single superphosphate $18 \% \mathrm{Ca}, 11 \% \mathrm{~S}$ and $21 \%$ of $\mathrm{P}_{2} \mathrm{O}_{5}$ ) in the planting line.

The experiment was conducted in a randomized blocks design, with 3 repetitions. The treatments were arranged in a fractional 
incomplete triple factorial $(3 / 4) 4^{2} \times 2$, totaling 72 experimental units. Four doses of $\mathrm{N}(46,69,92$ and $\left.115 \mathrm{~kg} \mathrm{ha}^{-1}\right)$ and four $\mathrm{K}_{2} \mathrm{O}$ doses $(62,93,124$ and $\left.155 \mathrm{~kg} \mathrm{ha}^{-1}\right)$ were combined in cottonseed fertilization in two areas, with 420 and $625 \mathrm{~g} \mathrm{~kg}^{-1}$ of clay. The fraction $3 / 4$ refers to the removal of 4 combinations of $\mathrm{N}$ and $\mathrm{K}_{2} \mathrm{O}$ from the complete factorial, $69 \times 155,92 \times 155,115 \times 93$ and $115 \times 124 \mathrm{~kg}$ $\mathrm{ha}^{-1}$, respectively. The description of the doses and sources of nutrients used in the experiment is described in Table 2, being the first the control treatment (fertilization commonly used on the farm). The other treatments were equivalent to an increase of 1.5, 2.0 and 2.5 times the doses used by the farm. The plots consisted of six lines of $10 \mathrm{~m}$ in length, with $0.76 \mathrm{~m}$ of spacing between lines, resulting in an useful area of $45 \mathrm{~m}^{2}$.

Table 1. Soil chemical analysis before the experiment implementation.

\begin{tabular}{|c|c|c|c|c|c|c|c|c|c|c|c|}
\hline \multicolumn{12}{|c|}{ Areal } \\
\hline Depth & $P^{(1)}$ & O.M.(2) & $\mathrm{pH}^{(3)}$ & $\mathrm{H}+\mathrm{Al}$ & $\mathrm{Al}^{3+}$ & $\mathrm{K}^{+(1)}$ & $\mathrm{Ca}^{2+(4)}$ & $\mathrm{Mg}^{2+(4)}$ & $\mathrm{SB}^{(5)}$ & $\mathrm{CEC}^{(6)}$ & $V^{(7)}$ \\
\hline $\mathrm{Cm}$ & $\mathrm{mg} \mathrm{dm}^{-3}$ & $\mathrm{~g} \mathrm{dm}^{-3}$ & & \multicolumn{6}{|c|}{$\mathrm{cmol}_{\mathrm{c}} \mathrm{dm}^{-3}$} & & $\%$ \\
\hline $0-20$ & 11.1 & 28 & 5.5 & 2.8 & 0 & 0.06 & 3.07 & 1.13 & 4.26 & 7.06 & 60.16 \\
\hline $20-40$ & 5.4 & 20 & 4.6 & 3.57 & 0.29 & 0.03 & 1.29 & 0.55 & 1.87 & 5.44 & 32.76 \\
\hline \multicolumn{12}{|c|}{ Area 2} \\
\hline Depth & $P^{(1)}$ & O.M. ${ }^{(2)}$ & $\mathrm{pH}^{(3)}$ & $\mathrm{H}+\mathrm{Al}$ & $\mathrm{Al}^{3+}$ & $\mathrm{K}^{+(1)}$ & $\mathrm{Ca}^{2+(4)}$ & $\mathrm{Mg}^{2+(4)}$ & $\mathrm{SB}^{(5)}$ & $\mathrm{CEC}^{(6)}$ & $V^{(7)}$ \\
\hline $\mathrm{Cm}$ & $\mathrm{mg} \mathrm{dm}^{-3}$ & $g \mathrm{dm}^{-3}$ & \multicolumn{7}{|c|}{$\mathrm{Cmol}_{\mathrm{c}} \mathrm{dm}^{-3}$} & & $\%$ \\
\hline $0-20$ & 8.4 & 34 & 4.8 & 5.05 & 0.20 & 0.09 & 2.18 & 0.85 & 3.12 & 8.17 & 37.50 \\
\hline $20-40$ & 1.6 & 22 & 4.3 & 4.79 & 0.56 & 0.05 & 0.69 & 0.33 & 1.07 & 5.85 & 18.01 \\
\hline
\end{tabular}

Table 2. Doses and sources of nutrients for each treatment.

\begin{tabular}{cccc}
\hline Treatments & Dose of nutrient $(\mathrm{Kg} / \mathrm{ha})$ & Souce & Dose fertilizer $\left(\mathrm{kg} \mathrm{ha}^{-1}\right)$ \\
\hline 1 & 46 of $\mathrm{N}$ and 62 of $\mathrm{K}_{2} \mathrm{O}$ & Urea $+\mathrm{KCl}$ & $100+100$ \\
2 & 69 of $\mathrm{N}$ and 62 of $\mathrm{K}_{2} \mathrm{O}$ & Urea $+\mathrm{KCl}$ & $150+100$ \\
3 & 92 of $\mathrm{N}$ and 62 of $\mathrm{K}_{2} \mathrm{O}$ & Urea $+\mathrm{KCl}$ & $200+100$ \\
4 & 115 of $\mathrm{N}$ and 62 of $\mathrm{K}_{2} \mathrm{O}$ & Urea $+\mathrm{KCl}$ & $250+100$ \\
5 & 46 of $\mathrm{N}$ and 93 of $\mathrm{K}_{2} \mathrm{O}$ & Urea $+\mathrm{KCl}$ & $100+150$ \\
6 & 46 of $\mathrm{N}$ and 124 of $\mathrm{K}_{2} \mathrm{O}$ & Urea $+\mathrm{KCl}$ & $100+200$ \\
7 & 46 of $\mathrm{N}$ and 155 of $\mathrm{K}_{2} \mathrm{O}$ & Urea $+\mathrm{KCl}$ & $100+250$ \\
8 & 69 of $\mathrm{N}$ and 93 of $\mathrm{K}_{2} \mathrm{O}$ & Urea $+\mathrm{KCl}$ & $150+150$ \\
9 & 92 of $\mathrm{N}$ and 124 of $\mathrm{K}_{2} \mathrm{O}$ & Urea $+\mathrm{KCl}$ & $200+200$ \\
10 & 115 of $\mathrm{N}$ and 155 of $\mathrm{K}_{2} \mathrm{O}$ & Urea $+\mathrm{KCl}$ & $250+250$ \\
11 & 69 of $\mathrm{N}$ and 124 of $\mathrm{K}_{2} \mathrm{O}$ & Urea $+\mathrm{KCl}$ & $150+200$ \\
12 & 92 of $\mathrm{N}$ and 93 of $\mathrm{K}_{2} \mathrm{O}$ & Urea $+\mathrm{KCl}$ & $200+150$ \\
\hline
\end{tabular}

The cotton cultivar used (Gossypium hirsutum L.) was FM 975 WS, with late cycle and resistant to the main crop larvae. Seeding was carried out in January, 2014 in the two areas, with 12 plants per linear meter. At 15 days after planting, a manual thinned was carried out to maintain the population of the experimental area with nine plants per linear meter (equivalent to 120 thousand plants $\mathrm{ha}^{-1}$ ). The cotton seeds were treated with Cropstar - 2.4 liters; Priori - 0.1 liters; Derosal Plus - 0.6 liters; Moceren 250 SC - 0.3 liters and Baytan - 0.2 liters, of the products for 100 $\mathrm{kg}$ of seeds.

The crop fertilization followed the procedures of commercial cultivation, in which
$154 \mathrm{~kg} \mathrm{ha}^{-1}$ MAP $\left(12 \% \mathrm{~N}\right.$ and $\left.52 \% \mathrm{P}_{2} \mathrm{O}_{5}\right)$ plus 100 $\mathrm{kg} \mathrm{ha}^{-1}$ of ammonium sulfate were applied to the sowing spot ( $21 \%$ of $\mathrm{N}$ and $23 \%$ of S). After 15 days of emergence, the fertilization was carried out with $90 \mathrm{~kg} \mathrm{ha}^{-1}$ of sulfur (source: sulfurgan, $90 \%$ of S) and granulated potassium with $62 \mathrm{~kg} \mathrm{ha}^{-1}$ of $\mathrm{K}_{2} \mathrm{O}$ (source $\mathrm{KCl}$, with $62 \%$ of $\mathrm{K}_{2} \mathrm{O}$ ) in the total area of the experiment, with the aid of a motorized equipment. It is noteworthy that the experiment was conducted in a first-year cotton area.

Nitrogen and potassium fertilization treatments were manually applied between the lines of the crop, and the doses were divided in two times at 33 and 66 days after emergence. Cultural treatments and phytosanitary 
management of the experimental plots followed the same procedures adopted in commercial cotton farming, including insect and disease monitoring, chemical weed control, insecticide applications, fungicides and growth regulators. To evaluate the yield of the crop (lint and seed), at 180 days after sowing, it was discarded one line on each side of the plot and $1 \mathrm{~m}$ from the ends of the four central lines. The manual harvesting of all bolls was carried out in the useful area of each plot, being four lines with $8 \mathrm{~m}$ in length.

The data were submitted to variance analysis and when significant differences were found between the treatments by the F test at the $5 \%$ probability level, the regression analysis was performed. The multiple regression models for response surface graphs were performed using the Im function of the Stats package of the $R$ software (R Foundation for Statistical Computing,
Vienna, Austria, 2008).

\section{Results and discussion}

There was a significant triple interaction between the applied doses of nitrogen and potassium and the soil clay content on cotton yield, which indicates the importance of the study of the response to fertilization for each soil, separately (Table 3). In the unfolding analysis, in both soils, the cotton yield did not differ as a function of the $\mathrm{N}$ doses when the highest $\mathrm{K}_{2} \mathrm{O}$ (155 $\mathrm{kg} \mathrm{ha}^{-1}$ ) dose was applied. However, for $\mathrm{K}_{2} \mathrm{O}$ doses, there was no difference in yield with the combination of the higher $\mathrm{N}$ doses $(92 \mathrm{and} 115 \mathrm{~kg}$ $\mathrm{ha}^{-1}$ ), only in the soil with $625 \mathrm{~g} \mathrm{~kg}^{-1}$ of clay (Table 3). The interaction between $N$ and $K$ is mentioned in the literature, in which the productivity response to the $\mathrm{N}$ application is lower when there is a low addition of $\mathrm{K}$ (Marschner, 2012).

Table 3. Summary of variance analysis for cotton yield $\left(\mathrm{kg} \mathrm{ha}^{-1}\right)$ as a function of the application of $\mathrm{N}$ and $\mathrm{K}_{2} \mathrm{O}$ doses in cover fertilization and the soil clay content.

\begin{tabular}{|c|c|c|c|c|c|c|c|c|c|c|c|c|}
\hline \multicolumn{4}{|c|}{ Main anava } & \multicolumn{9}{|c|}{ Unfolding Anava } \\
\hline \multirow{2}{*}{$\begin{array}{l}\text { Source of } \\
\text { variation }\end{array}$} & \multirow{2}{*}{$\frac{\text { DF }}{2}$} & \multirow{2}{*}{$\begin{array}{c}\text { MS } \\
18715\end{array}$} & \multirow{2}{*}{$\begin{array}{c}\text { Pvalue } \\
0.741\end{array}$} & \multirow{2}{*}{$\begin{array}{l}\mathrm{DF} \\
3\end{array}$} & \multicolumn{2}{|c|}{$\begin{array}{c}\mathrm{N} \\
\text { Clay/K }\end{array}$} & \multirow{2}{*}{$\begin{array}{c}\text { QM } \\
447395\end{array}$} & \multirow{2}{*}{$\begin{array}{l}\text { Pvalue } \\
0.000\end{array}$} & \multicolumn{2}{|c|}{$\begin{array}{c}\mathrm{K} \\
\text { Clay/N }\end{array}$} & \multirow{2}{*}{$\begin{array}{c}\text { QM } \\
226452\end{array}$} & \multirow{2}{*}{$\begin{array}{l}\text { Pvalue } \\
0.018\end{array}$} \\
\hline & & & & & 42 & 62 & & & 42 & 46 & & \\
\hline Clay & 1 & 87951374 & 0.000 & 2 & 42 & 93 & 650474 & 0.000 & 42 & 69 & 224385 & 0.033 \\
\hline N & 3 & 804884 & 0.000 & 2 & 42 & 124 & 971970 & 0.000 & 42 & 92 & 762076 & 0.000 \\
\hline $\mathrm{K}_{2} \mathrm{O}$ & 3 & 592139 & 0.000 & 1 & 42 & 155 & 22816 & 0.546 & 42 & 115 & 1155448 & 0.000 \\
\hline Clay*N & 3 & 516540 & 0.000 & 3 & 62 & 46 & 257366 & 0.011 & 62 & 46 & 202135 & 0.029 \\
\hline $\mathrm{Clay}^{*} \mathrm{~K}_{2} \mathrm{O}$ & 3 & 285239 & 0.007 & 2 & 62 & 93 & 598086 & 0.000 & 62 & 69 & 769160 & 0.000 \\
\hline $\mathrm{N}^{*} \mathrm{~K}_{2} \mathrm{O}$ & 5 & 455250 & 0.000 & 2 & 62 & 124 & 450204 & 0.002 & 62 & 92 & 123337 & 0.145 \\
\hline Clay*N* $\mathrm{K}_{2} \mathrm{O}$ & 5 & 262662 & 0.003 & 1 & 62 & 155 & 75264 & 0.276 & 62 & 115 & 22570 & 0.549 \\
\hline Residue & 46 & 61950 & & & & & 61950 & & & & 61950 & \\
\hline Total & 71 & & & & & & & & & & & \\
\hline \multicolumn{2}{|c|}{ Mean $\left(\mathrm{kg} \mathrm{ha}^{-1}\right)$} & 3853,62 & & & & & & & & & & \\
\hline CV \% & & 6.46 & & & & & & & & & & \\
\hline
\end{tabular}

The $\mathrm{N}$ application significantly increased the cotton yield in the area with lower clay content. The yield presented quadratic behavior as a function of the $\mathrm{N}$ doses, when 62, 93 and $124 \mathrm{~kg} \mathrm{ha}^{-1}$ of $\mathrm{K}_{2} \mathrm{O}$ were applied. The maximum yield points of the equations are 2740, 3228 and $3528 \mathrm{~kg} \mathrm{ha}^{-1}$ of cotton, with the respective doses 70,75 and $81 \mathrm{~kg} \mathrm{ha}^{-1}$ of $\mathrm{N}$ (Figure 2A). Thus, it is evident that the highest yield was obtained with the application of $81 \mathrm{~kg} \mathrm{ha}^{-1}$ of $\mathrm{N}$ and 124 $\mathrm{kg} \mathrm{ha}^{-1}$ of $\mathrm{K}_{2} \mathrm{O}$. Quadratic behavior is observed when there is abundant nutrient supply and an inversion of the tendency caused by nutrient toxicity or by the induced deficiency of another nutrient (Marschner, 2012). Excessive $N$ uptake is not benefic for increasing the cotton yield because it promotes excessive vegetative growth (Yeates et al., 2010). The $\mathrm{N}$ levels in the soil left by the previous crop (soybean) may also have influenced the excess of $\mathrm{N}$ added (Geng 
et al., 2015).

The cotton yield in the experiment with the highest clay content $\left(625 \mathrm{~g} \mathrm{~kg}^{-1}\right)$ increased linearly with the application of $\mathrm{N}$ when $93 \mathrm{~kg} \mathrm{ha}^{-1}$ of $\mathrm{K}_{2} \mathrm{O}$ was added. On the other hand, when the $\mathrm{N}$ doses were combined with a dose of 124 $\mathrm{kg} \mathrm{ha}^{-1}$ of $\mathrm{K}_{2} \mathrm{O}$, there was a quadratic response, with a maximum of $5515 \mathrm{~kg} \mathrm{ha}^{-1}$ of cotton at the dose $71 \mathrm{~kg} \mathrm{ha}^{-1}$ of $\mathrm{N}$ (Figure 2B). Similar results were reported by Zhang et al. (2012) and Geng et al. (2015), which also obtained increasing productivity due to the application of $\mathrm{N}$ in cotton. In the area with lower clay content,

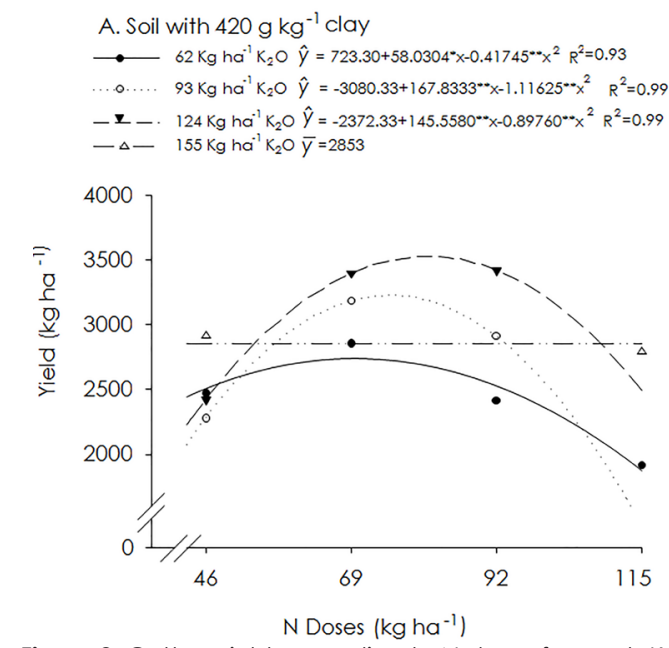

Figure 2. Cotton yield according to $\mathrm{N}$ doses for each $\mathrm{K}_{2} \mathrm{O}$ dose provided on soils with $420 \mathrm{~g} \mathrm{~kg}^{-1}$ of clay $(\mathrm{A})$ and with $625 \mathrm{~g} \mathrm{~kg}^{-1}$ of clay (B).

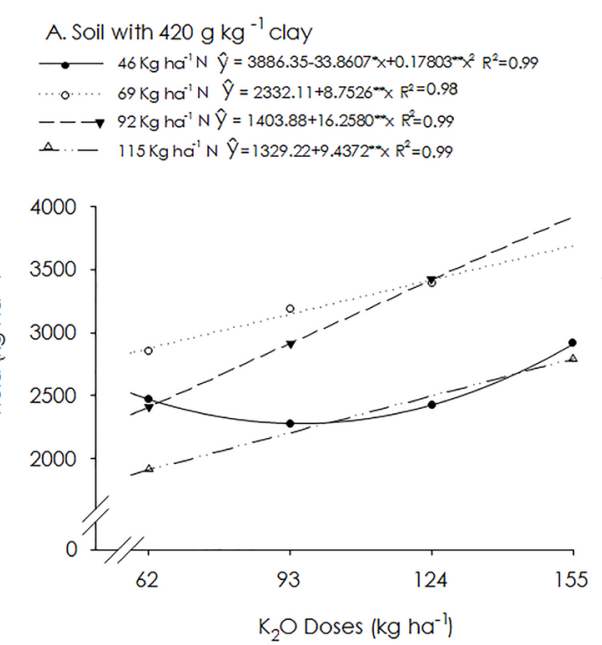

cotton yield, as a function of $\mathrm{K}_{2} \mathrm{O}$ doses, a quadratic behavior was observed, at the lowest (46 kg ha-1) and the highest (115 kg ha-1) N dose. Intermediate doses (69 and $92 \mathrm{~kg} \mathrm{ha}^{-1} \mathrm{~N}$ ) resulted in a linear increase in yield, which indicates the possibility of higher yields with increasing $\mathrm{K}_{2} \mathrm{O}$ doses up to $155 \mathrm{~kg} \mathrm{ha}^{-1}$ (Figure 3A). In the state of Goiás, Brazil, in an area with $560 \mathrm{~g} \mathrm{~kg}^{-1}$ of clay, Bernardi et al. (2009) evaluated the application of $\mathrm{K}_{2} \mathrm{O}$ doses in the cotton crop and verified that the highest yield $\left(4,172 \mathrm{~kg} \mathrm{ha}^{-1}\right)$ was obtained with the dose of $240 \mathrm{~kg} \mathrm{ha}^{-1}$ of $\mathrm{K}_{2} \mathrm{O}$ applied in the sowing furrow.

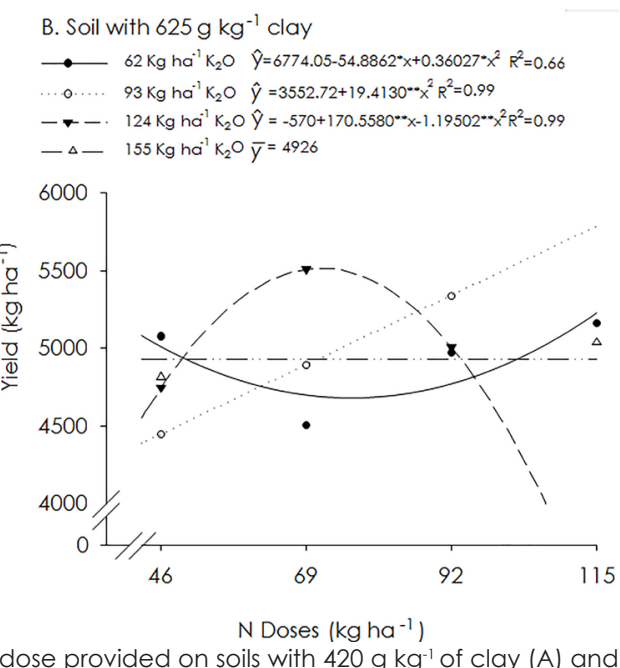

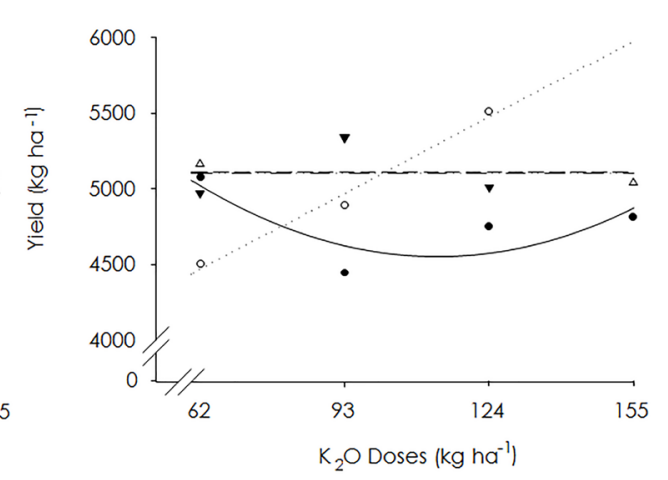

Figure 3. Cotton yield according to $\mathrm{K}_{2} \mathrm{O}$ doses for each $\mathrm{N}$ dose provided on soils with $420 \mathrm{~g} \mathrm{~kg}^{-1}$ of clay (A) and $625 \mathrm{~g} \mathrm{~kg}^{-1}$ of clay (B).

In the area with higher clay content, there was a difference in yield according to the $\mathrm{K}_{2} \mathrm{O}$ doses, only when the lowest $\mathrm{N}$ doses (46 and $69 \mathrm{~kg} \mathrm{ha}^{-1} \mathrm{~N}$ ) were applied. On the other hand, there was no difference in yield as a function of

$\mathrm{K}_{2} \mathrm{O}$ doses when the highest $\mathrm{N}$ doses (92 and 115 $\mathrm{kg} \mathrm{ha}^{-1} \mathrm{~N}$ ) were used (Figure 3B).

An explanation for these results is the higher K buffer power in the soil with higher content of clay and organic matter, since theoretically it is 
able to maintain a more stable concentration of $K$ as the potassium fertilizer is added. In addition, the soil with higher clay content has a higher $\mathrm{K}$ amount than the area with a lower clay content, since the CEC and the percentage of potassium saturation are higher (Table 1) (Ernani et al., 2007). In addition, the $K$ intensity in the soil, before application of the treatments, was higher than in the soil with $420 \mathrm{~g} \mathrm{~kg}^{-1}$ of clay, since the available $K$ content was classified as medium, while in the soil with lower clay content it was classified as low (Sousa and Lobato, 2004).

The management history of the experiment areas explains the higher availability of $\mathrm{K}$ in the area with higher clay content, because the cotton was cultivated after corn-soybean succession, while in the area with lower clay content the cotton was grown after a fallowsoybean succession. So corn straw may have provided additional $\mathrm{K}$ by cycling the nutrient in the area with the highest clay content. The $\mathrm{K}$ ion is predominantly in the plant as free cation and can be easily leached from plant tissues that cover the soil (Marschner, 2012). Crop rotation increases soil cover and consequently can increase the organic matter content in cotton production systems (Senapati et al., 2014).

Analyzing the dynamics of some soil attributes, Borin et al. (2015) suggests that a suitable soil for cotton cultivation in the 'Cerrado' region should have an average O.M. between
15 and $30 \mathrm{~g} \mathrm{dm}^{-3}$. In the two studied areas, values close to those recommended by the author (Table 1) were observed, however, the soil with the highest O.M. content resulted in highest yields. Among the beneficial effects of the soil organic matter, it is important to highlight the soil microorganism stimulation, soil physical conditioning, biological and chemical buffering, thermal control and better water retention (Boulal et al., 2011) . Thus, the higher O.M. content in the area with higher clay content may also have contributed to a more efficient utilization of $\mathrm{K}$ fertilizers and higher yields.

The study of the response surface of cotton yield in the two areas showed that the yield varied from 1914 to $3422 \mathrm{~kg} \mathrm{ha}^{-1}$ in the area with $420 \mathrm{~g} \mathrm{~kg}^{-1}$ of clay. However, in the area with $625 \mathrm{~g} \mathrm{~kg}^{-1}$ of clay, the yield ranged from 4446 to $5509 \mathrm{~kg} \mathrm{ha}^{-1}$, confirming the yield difference in areas with different clay contents (Figure 4). Yield response curves are strongly influenced by interactions between nutrients and other growth factors. In field conditions, interactions between water availability and $N$ supply are particularly important. Lower yields, even with adequate nutrient supply, may be caused by the delay of the stomata opening in response to water deficiency, higher water consumption and water deficit in vegetative stages and also by the increase of the shoot growth rate when compared to root (Marschner, 2012).

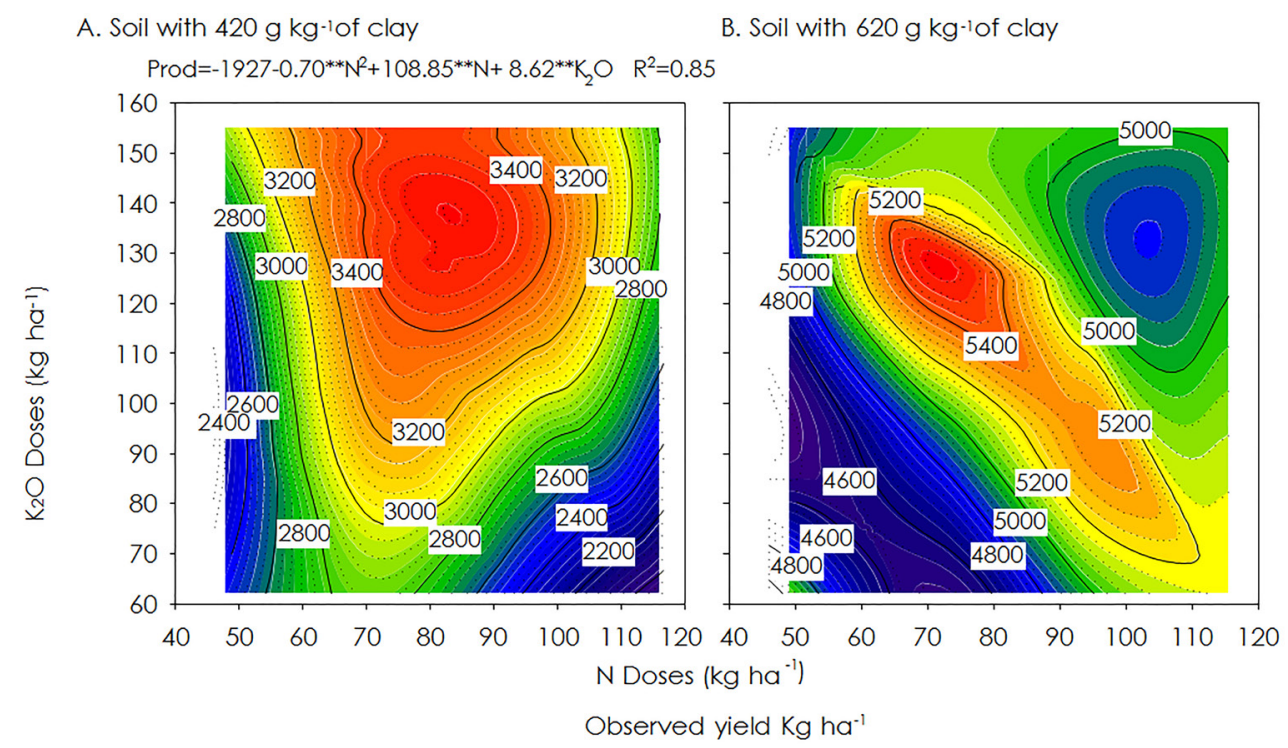

Figure 4. Response surface for cotton yield on soil with $420 \mathrm{~g} \mathrm{~kg}^{-1}$ of clay (A) and with $625 \mathrm{~g} \mathrm{~kg}^{-1}$ of clay (B) according to nitrogen and potassium doses provided on cover fertilization. 
The relationship between soil texture and crop yield is considered in some research studies (Bedin et al., 2003; Klein et al., 2010), which highlight the high correlation of this soil physical characteristic with yield and its importance for the land evaluation for agricultural use. Cotton yields in both areas were higher than the national average of $2,998 \mathrm{~kg} \mathrm{ha}^{-1}$ in the $2013 / 14$ crop years (Conab, 2014).

Based on the mathematical equation, the maximum yield of the area with the lowest clay content $\left(420 \mathrm{~g} \mathrm{~kg}^{-1}\right)$ was verified with the application of $78 \mathrm{~kg} \mathrm{ha}^{-1}$ of $\mathrm{N}$ and $155 \mathrm{~kg} \mathrm{ha}^{-1}$ of $\mathrm{K}_{2} \mathrm{O}$ in cover fertilization (Figure $3 \mathrm{~A}$ ). Evaluating the combined application of $\mathrm{N}$ and $\mathrm{K}$ doses during two years, Dong et al. (2010) obtained cotton yield variation from 1451 to $2087 \mathrm{~kg} \mathrm{ha}^{-1}$. The authors also noticed a significant increase in cotton yield as a function of nitrogen and potassium fertilization.

In the soil with higher clay content (Figure 3B) differences were observed between the treatments by the $\mathrm{F}$ test at $5 \%$ of probability, but the mathematical models studied did not represent significantly the response behavior in cotton yield as a function of the two applied nutrients. For this reason, a multiple regression model was not presented, so Figure 3B shows only the response surface of the values observed in the field without the mathematical model.

The highest yields observed in the treatments containing $\mathrm{N}$ and $\mathrm{K}$ together in adequate doses in the areas with different clay content could be explained by the demand, function and interaction of these nutrients. $N$ is a nutrient absorbed in large quantities by cotton, which accumulates during its cycle from 50 to 85 $\mathrm{kg}$ of $\mathrm{N}$ to produce one ton of cotton (Rochester, 2007). Photosynthesis is strongly reduced in plants deficient in $\mathrm{N}$ and $\mathrm{K}$. Potassium nutrition affects photosynthesis mainly because of K's function in the regulation of stomata opening, which interferes with the assimilation of $\mathrm{CO}_{2}$. On the other hand, the excess supply of $\mathrm{K}$ can cause a consumption without need, with possible interference in the absorption and availability of $\mathrm{Ca}$ and $\mathrm{Mg}$ (Marschner, 2012). As N or K deficiency becomes more severe in cotton, there may be yield losses, as there is a synergistic effect between the two nutrients (Borin et al., 2015).

The coefficient of determination of 0.89 in the multiple regression model with the variables $\mathrm{N}, \mathrm{K}$ and clay content indicates that clay variation interferes with cotton yield (Figure 4). According to Klein et al. (2010) description, the higher the clay content, the higher the cotton yield. Therefore, it is necessary to make a recommendation for nitrogen and potassium fertilization, taking also into consideration the clay content present in the soil, as it directly influences the cation exchange capacity (CEC) and the availability of these nutrients in the soil.

Studies indicate that the $\mathrm{N}$ doses in fertilization to achieve the higher potential yield of the crop should take into consideration the soil type (Yang et al., 2012; Luo et al., 2010). The

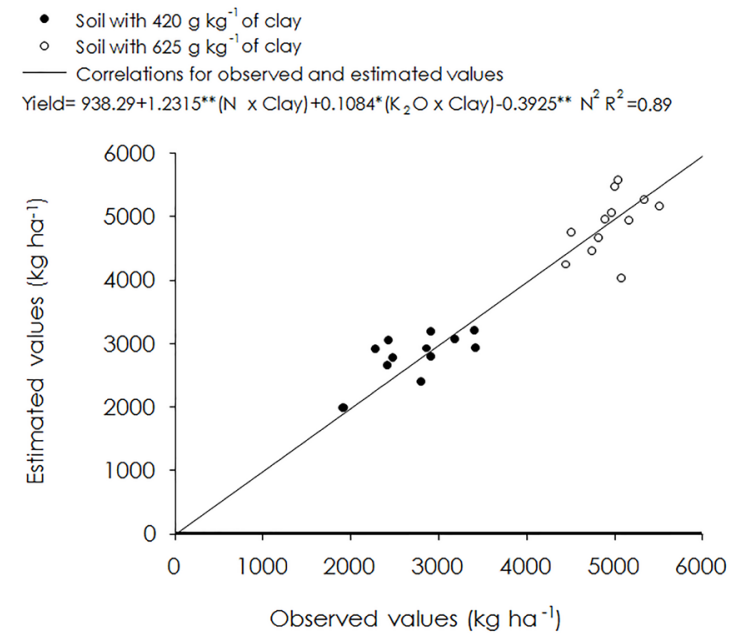

Figure 4. Correlation between observed and estimated values for cotton yield using a linear multiple model, considering $\mathrm{N}$ and $\mathrm{K}_{2} \mathrm{O}$ doses and clay contents. 
adequate use of soil chemical and physical analysis for the application of $K$ fertilizers is important because it allows higher economic savings (Harper et al., 2012). The results of the present study are in accordance to literature and affirm the importance of taking into consideration the clay content in the expectation of cotton yield and for the greater efficiency of the use of nitrogen and potassium fertilizers in the crop.

\section{Conclusions}

1. The cotton yield depends on the clay content of the soil.

2. Appropriate doses of $\mathrm{N}$ and $\mathrm{K}$ applied together in cover fertilization increase up to 1508 and $1063 \mathrm{~kg} \mathrm{ha}^{-1}$ the cotton yield in soils with 420 and $625 \mathrm{~g} \mathrm{~kg}^{-1}$ of clay, respectively.

3. In the experiment conditions it is suggested the application of $78 \mathrm{~kg} \mathrm{ha}^{-1}$ of $\mathrm{N}$ and $155 \mathrm{~kg} \mathrm{ha}^{-1}$ of $\mathrm{K}_{2} \mathrm{O}$ in cover in soils with clay content of $420 \mathrm{~g} \mathrm{~kg}^{-1}$ and $71 \mathrm{~kg} \mathrm{ha}^{-1}$ of $\mathrm{N}$ and 124 $\mathrm{kg} \mathrm{ha}^{-1}$ of $\mathrm{K}_{2} \mathrm{O}$ in cover in soils with clay content of $625 \mathrm{~g} \mathrm{~kg}^{-1}$.

\section{Acknowledgments}

The authors would like to thank CAPES for the scholarship to the first author, ABC Agricola for funding the experiment and for the researchers of the MT Foundation for the technical support

\section{References}

Bedin, I., Furtini Neto, A.E., Resende, A.V., Faquin, V., Tokura, A.M., Santos, .Z.L. 2003. Fertilizantes fosfatados e produção da soja em solos com diferentes capacidades tampão de fosfato. Revista Brasileira de Ciência do Solo 27:639- 646.

Bernardi, A.C. de C., Oliveira Júnior, J.P. de, Leandro, W.M., Mesquita, T.G. da S., Freitas, P.L. de, Carvalho, M. da C.S. 2009. Doses e formas de aplicação da adubação potássica na rotação soja, milheto e algodão em sistema plantio direto. Pesquisa Agropecuária Tropical 39: 158167.

Bondada, B.R., Oosterhuis, D.M. 2013. Canopy photosynthesis, specific leaf weight, and yield components of cotton under varying nitrogen supply. Journal of Plant Nutrition 3: 469-477.

Borin, A.L.D.C., Carvalho, M. da C.S., Ferreira, G.B. 2015. Nutrição, calagem e adubação do algodoeiro. In: Freire, E.C. Algodão no cerrado do Brasil. Editora Positiva, Brasília-DF, Brasil. p. 485531.
Boulal, H., Gómez-Macpherson, H., Gómez, J.A.,Mateos, L. 2011 . Effect of soil management and traffic on soil erosion in irrigated annual crops. Journal Soil \& Tillage Research 115: 62-70.

CONAB- Companhia nacional de abastecimento. Acompanhamento da safra brasileira de grãos 2013/2014, 101p. 2014. http://www.conab.gov.br/ OlalaCMS/uploads/ arquivos/14_06_10_12_12_37_boletim_graos_ junho_2014.pdf. <Acesso em 30 jul. 2015>.

Devkota, M., Martius, C., Lamers, J.P.A., Sayre, K.P., Devkota, K.P., Vlek, P.L.G. 2013. Tillage and nitrogen fertilization effects on yield and nitrogen use efficiency of irrigated cotton. Journal Soil \& Tillage Research 134: 72-82.

Dong, H., Kong, X., LI, W., Tang, W., Zhang, D. 2010. Effects of plant density and nitrogen and potassium fertilization on cotton yield and uptake of major nutrients in two fields with varying fertility. Journal Field Crops Research 119: 106-113.

Ernani, P.R., Almeida, J.A., Santos, F.C. 2007. Potássio. In: Novais, R.F., Alvarez, V.H., Barros, N.F., Fontes, R.L.F., Cantarutti, R.B., Neves, J.C.L. Fertilidade do solo. Sociedade Brasileira de Ciência do Solo (SBCS/UFV), Viçosa-MG. p. 551594.

FAO, Food and Agriculture Organization of the United Nations \& ICAC, World Apparel Fibre Consumption Survey. Food and Agriculture Organization of the United Nations/International Cotton Advisory Committee, Washington, DC. 2013. https://www.fao.org.br. <Acesso em 24 Jul. 2015>.

Franzluebbers, A.J., Hubbs, M.D., Norfleet, M.L., 2012. Evaluating soil organic carbon sequestration potential in the Cotton Belt with the soil conditioning index. Journal Soil Water Conservation 67: 378-389.

Fultz, L.M., Moore-Kucera, J., Zobeck, T.M., AcostaMartı́nez, V., Wester, D.B., Allen, V.G., 2013. Organic carbon dynamics and soil stability in five semiarid agroecosystems. Journal Agriculture Ecosystems \& Environment 181: 231-240.

Geng, J., Ma, Q., Zhang, M., Li, C., Liu, Z., Lyu, X., Zheng, W. 2015. Synchronized relationships between nitrogen release of controlle drelease nitrogen fertilizers and nitrogen requirements of cotton. Journal Field Crops Research 184: 9-16.

Harper, D. C., Lambert, D. M., Larson, J. A., Gwathmey, C. O. 2012. Potassium carryover dynamics and optimal application policies in cotton production. Journal Agricultural Systems 106: 84-93.

Kintche, K., Guibert, H., Sogbedji, J.M., Leveque, J., Tittonell, P. 2010. Carbon losses and primary 
productivity decline in savannah soils under cotton-cereal rotations in semiarid Togo. Journal Plant and Soil 336: 469-484.

Klein, V.A., Baseggio, M., Madalosso, T., Marcolin, C.D. 2010. Textura do solo e a estimativa do teor de água no ponto de murcha permanente com psicrômetro. Ciência Rural, Santa Maria 40: 1550 1556.

Luo, X., Chen, B., Zhang, J., Jiang, P. 2010. Effect of nitrogen applied levels on the dynamics of biomass, nitrogen accumulation of cotton plant in different soil textures. Journal of Soil Science 41: 904-910

Marschner, P. 2012. Marschner 's mineral nutrition of higher plants. $3^{\circ} \mathrm{ed}$. New York, Academic Press $651 \mathrm{p}$.

Pettigrew, W.T., 2008. Potassium influences on yield and quality production formaize, wheat, soybean and cotton. Physiologia Plantarum 133: 670-681.

R Development Core Team. 2008. R: A language and environment for statistical computing. $R$ Foundation for Statistical Computing, Vienna, Austria. ISBN 3-900051-07-0, URL http://www.Rproject.org.

Rochester, I.J. 2007. Nutrient uptake and export from an Australian cotton field. Nutrient Cycling in Agroecosystems 77:213-223.

Rochester, I.J., 2011. Assessing internal crop nitrogen use efficiency in high-yielding irrigated cotton. Nutrient Cycling in Agroecosystems 90:147-156.

Santos, H.G. dos; Jacomine, P.K.T.; Anjos, L.H.C. dos; Oliveira, V.A. de; Lumbreras, J. F.; Coelho, M.R.; Almeida, J. A. de; Cunha, T.J.F.; Oliveira, J.B. de. Sistema brasileiro de classificação de solos. Brasília: Embrapa, 2013. 353p.

Senapati, N., Hulugalle, N.R., Smith, P., Wilson, B.R., Yeluripati, J.B., Daniel, H., Ghosh, S., Lockwood, P. 2014. Modelling soil organic carbon storage with RothC in irrigated Vertisols under cotton cropping systems in the sub-tropics. Journal Soil \& Tillage Research 143: 38-49.

Sousa, D.M.G., Lobato, E. 2004. Cerrado: correção do solo e adubação. Planaltina-GO, Embrapa Cerrados, $416 \mathrm{p}$.

Souza, R. de F., Leandro, W.M., Silva, N.B. da, Cunha, P.C.R. da, Ximenes, P.A. 2011 . Diagnose nutricional pelos métodos dris e faixas de concentração para algodoeiro cultivado sob cerrado. Pesquisa Agropecuária Tropical 41: 220228.

Yang, G., Tang, H., Tong, J., Nie, Y., Zhang, X.
2012. Effect of fertilization frequency on cotton yield and biomass accumulation. Journal Field Crops Research 125: 161-166.

Yeates, S.J., Constable, G.A., Mccumstie, T. 2010. Irrigated cotton in the tropical dryseason. II: biomass accumulation, partitioning and RUE. Journal Field Crops Research 1 16: 290-299.

Zhang, D.M., Li, W.J., Xin, C.S., Tang, W., Eneji, A.E., Dong, H.Z. 2012. Lint yield and nitrogen use efficiency of field-grown cotton vary with soil salinity and nitrogen application rate. Journal Field Crops Research 138: 63-70.

Zhao, S., He, P., Qui, S., Jia, L., Liu, M., Jim, J., Johnston, A.M. 2014. Long-term effects of potassium fertilization and straw return on soilpotassium levels and crop yields in northcentral China. Journal Field Crops Research 169: 116-122. 